\title{
Effect of grazing versus indoors feeding on the damage done to the grass during ingestive mastication
}

\author{
A. Boudon ${ }^{1,3}$, A. Acosta ${ }^{2}$, R. Delagarde ${ }^{1}$ and J.-L. Peyraud ${ }^{1}$ \\ ${ }^{1}$ Unité Mixte de Recherches INRA/Agrocampus Production du Lait, \\ Institut National de la Recherche Agronomique, 35590 St-Gilles, France \\ ${ }^{2}$ Universidad de Buenos Aires, Facultad de Agronomía \\ Av. San Martin, 4453 Ciudad de Buenos Aires, Argentina
}

\begin{abstract}
This experiment compared the effect of grazing versus indoors feeding of ryegrass, on the chewing behaviour and the physical damage done to the grass during ingestive mastication in dairy cows. Ingestive boli were collected on four cows fed at grazing or indoors in a triple reversal design. The cows ingested smaller boli ( 93.4 vs $142.2 \mathrm{~g} ; \mathrm{P}<0.01)$ at a slower rate at grazing compared to indoors feeding. The proportions of cell contents released during mastication and the proportions of particles in the boli shorter than $2 \mathrm{~mm}$ were noticeably higher at grazing compared to indoors feeding. The consequence could be a higher rate of ruminal digestion of grass at grazing compared to indoors feeding.
\end{abstract}

KEY WORDS: mastication, cell contents, particle size, ruminal digestion, green forage

\section{INTRODUCTION}

Ingestive mastication of ruminants is different at grazing compared to indoors feeding due to the effort produced to grasp the tillers (Laca et al., 1994). The consequences could be a higher physical damage done to the grass during ingestion at grazing and a higher ruminal rate of digestion. Our objective was to compare the effect of grazing vs indoors feeding on chewing behaviour, release of cell contents (CC) and comminution of particle during ingestion in dairy cows.

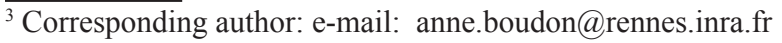




\section{MATERIAL AND METHODS}

\section{Animals and feeding}

Two treatments, grazing or indoors feeding of perennial ryegrass (Lolium perenne L., cv Belfort) were compared on four dairy cows. The statistical design was a triple reversal trial type $\mathrm{ABABAB}$ and comprised 6 experimental periods of two days. During the experimental periods, ingestive boli were collected during short meals of 30 min after the morning milking. During these meals, two animals were fed indoors and two others were grazing according to the experimental design. During the reminding of the day, the four animals were held on the same feeding system, on the same grass as offered for the test meals. The animals grazed after the morning milking and were fed indoors after the evening milking. To maintain a high motivation to eat for the collection of boli, the access to the trough was suppressed in the night between 22.00 and 8.00 .

\section{Sampling and measurements}

The first day of each period, boli were collected on one grazing animal and one animal fed indoors. On the second day, the boli were collected on the two other animals. Each day, the boli were collected first on the grazing animal. To achieve this, its rumen contents was removed by hand and the animal was allowed to graze a mini plot of 16 $\mathrm{m}_{\mathrm{c}}$ for $30 \mathrm{~min}$. During this meal, thirty boli were collected directly at the cardia. The second grazing animal was in an adjacent mini plot. The total eating time, the duration of collection of boli, the number of jaw movements and the number of boli in each sequence of collection were manually recorded. Then, the rumen was refilled. The boli were then collected on an animal fed indoors, as described for grazing, except that a small test meal of $7 \mathrm{~kg}$ herbage was offered. After the collection of the boli, the four animals were allowed to graze together. The studied CC comprised the intracellular nitrogen and the neutral detergent soluble (NDS=100-NDF). For the measurement of the proportion of $\mathrm{CC}$ released by ingestive mastication, subsamples of boli were rinsed, with $3 \mathrm{~L}$ of distilled water per $100 \mathrm{~g}$ of boli, on a $100 \mu \mathrm{m}$ mesh nylon cloth, to remove the $\mathrm{CC}$ released from the plant cells during mastication. The proportion of $\mathrm{CC}$ released was defined as the difference between the quantity of $\mathrm{CC}$ ingested for the bolus and the quantity of $\mathrm{CC}$ remaining in the bolus after rinsing divided by the quantity of $\mathrm{CC}$ ingested for the bolus. The formula and the methods of analyses were given by Boudon and Peyraud (2001). The particle size distribution of the boli were measured by wet sieving on a electromagnetic siever (Analysette 3, Fritsch) with 7 sieves. Sieve sizes (length of the side of square hole) were 16, 10, 4, 2, 1, 0.5, $0.063 \mathrm{~mm}$.

Each day of collection of boli, representative samples of the grass offered to the animals fed indoors were taken. To obtain a representative sample of the grass eaten by the grazing animals, herbage handfuls were cut at the ground level, just before the entry of the animal of its mini plot. This sample was arranged 
in a metallic tray to keep the sward structure undamaged before to be cut at the observed mean post grazing height. The upper portion was considered as representative of the grass eaten. For the measurement of the post grazing height, the extended height to ground level of the longest leaf and sheath of 60 and 120 tillers were measured before and after grazing respectively.

\section{Statistical analyses}

The data were analysed by analysis of variance using the GLM procedure of SAS (SAS Inc.). For the parameters related to the boli or the chewing behaviour, the model sums of squares were separated into effect due to treatment (grazing or indoors feeding), animal, period, animal $\times$ treatment and period $\times$ treatment. For the parameters related to the offered herbage, the model sums of squares were separated into effects due to treatment, period, day in period and period $\times$ treatment.

\section{RESULTS AND DISCUSSION}

The initial structure of the swards used for indoors feeding and for grazing were not different (Table 1). The post-cutting height was $18.1 \mathrm{~mm}$ higher than the post-grazing height. However, the consequences on the chemical composition of the ingested grass were quite low given that the NDF contents was not different between indoor feeding and grazing. The total $\mathrm{N}$ content was only $0.24 \mathrm{~g} / \mathrm{kg}$ lower with indoor feeding compared to grazing.

Table 1. Characteristics of the ingested grass in animals fed indoors or grazing

\begin{tabular}{lcccccc}
\hline \multirow{2}{*}{ Indices } & \multicolumn{2}{c}{ Treatments } & & $\begin{array}{c}\text { Level of } \\
\text { significance }\end{array}$ & \multirow{2}{*}{ Std } \\
\cline { 2 - 3 } \cline { 2 - 3 } & indoors & grazing & & treatment & \\
\hline Tiller pre-cutting or grazing height, $\mathrm{mm}$ & 200.7 & 200.2 & & $\mathrm{NS}$ & 7.3 \\
Sheaths pre-cutting or grazing height, $\mathrm{mm}$ & 50.3 & 48.5 & & $\mathrm{NS}$ & 2.7 \\
Tiller post-cutting or grazing height, $\mathrm{mm}$ & 117.9 & 99.8 & & $* *$ & 9.4 \\
NDF contents & $2 \mathrm{~g} / \mathrm{kg} \mathrm{NM}$ & 46.2 & 45.6 & & $\mathrm{NS}$ & 1.7 \\
Total N contents, $\mathrm{g} / \mathrm{kg} \mathrm{DM}$ & 4.03 & 4.27 & & $*$ & 0.18 \\
\hline
\end{tabular}

${ }^{1} \mathrm{NS}$ - $\mathrm{P}>0.05, * \mathrm{P}<0.05, * * \mathrm{P}<0.01 ;{ }^{2} \mathrm{NDF}$ - neutral detergent fibre

The animals fed indoors compared to grazing animals, ingested bigger boli (Table 2). This was illustrated by a higher fresh weight of the boli and it was accentuated on the dry weight due to a higher dry matter content of the boli with indoors feeding. The intake rate was also noticeably higher with the animals fed indoors but the frequency of jaw movements was not affected by the treatments.

The proportions of NDS and intracellular $\mathrm{N}$ released by ingestive mastication were lower in animals fed indoors compared to grazing animals. This was coherent with the lower proportion of soluble released during wet sieving. Moreover, the 
proportions of particles of the boli passing the $2 \mathrm{~mm}$ sieve was lower in animals fed indoors compared to the grazing ones.

Table 2. Effect of grazing vs indoors feeding on the chewing behaviour, release of cell contents and particles size of the ingested boli

\begin{tabular}{|c|c|c|c|c|c|}
\hline \multirow[t]{2}{*}{ Indices } & \multicolumn{2}{|c|}{ Treatments } & \multicolumn{2}{|c|}{$\begin{array}{c}\text { Level of } \\
\text { significance }^{1}\end{array}$} & \multirow[t]{2}{*}{ Std } \\
\hline & Indoors & grazing & treat. & anim. & \\
\hline \multicolumn{6}{|l|}{ Chewing behaviour } \\
\hline fresh weight of ingested boli, $g$ & 142.2 & 93.4 & $* * *$ & NS & 7.3 \\
\hline dry weight of ingested boli, $g$ & 12.89 & 7.73 & $* *$ & NS & 2.2 \\
\hline intake rate, $\mathrm{g} \mathrm{DMI} / \mathrm{min}$ & 52.17 & 22.94 & $* *$ & NS & -11.5 \\
\hline frequency of jaw movements, /min & 56.91 & 53.83 & NS & NS & 4.40 \\
\hline \multicolumn{6}{|c|}{ Physical damage done to the grass during ingestive mastication } \\
\hline NDS released ${ }^{2}, \mathrm{~g} / 100 \mathrm{~g}$ ingested & 14.4 & 25.3 & * & NS & 8.3 \\
\hline intracellular $\mathrm{N}$ released, $\mathrm{g} / 100 \mathrm{~g}$ ingested & 19.4 & 31.8 & $* *$ & NS & 8.5 \\
\hline proportion of particles $<2 \mathrm{~mm}, \mathrm{~g} / 100 \mathrm{~g}$ & 17.72 & 25.83 & $* *$ & $*$ & 4.99 \\
\hline proportion of soluble ${ }^{3}, \mathrm{~g} / 100 \mathrm{~g} \mathrm{DM}$ & 21.49 & 28.50 & * & NS & 6.68 \\
\hline
\end{tabular}

${ }^{1} \mathrm{NS}-\mathrm{P}>0.05,{ }^{*} \mathrm{P}<0.05,{ }^{*} \mathrm{P}<0.01, * * * \mathrm{P}<0.001 ;{ }^{2} \mathrm{NDS}$ - neutral detergent soluble; ${ }^{3}$ the soluble was defined as the matter passing the $0.063 \mathrm{~mm}$ sieve

The effect of indoors feeding vs grazing on the boli characteristics were very noticeable in this experiment. These large effects may be due to the fact that the animals were fasted before the boli collection and that the easiness of prehension of the grass at grazing was low due to a low total sward height (Laca et al., 1994).

\section{CONCLUSIONS}

The physical damage done to the grass during ingestive mastication of dairy cows was higher at grazing compared to indoors feeding. This may suggest the rate of digestion and the rate transit of grass in the rumen could be lower with zero grazing compared to grazing situations.

\section{REFERENCES}

Boudon A., Peyraud J.-L., 2001. The release of intracellular constituents from fresh ryegrass (Lolium perenne L.) during ingestive mastication in dairy cows: effect of intracellular constituent, season and stage of maturity. Anim. Feed Sci. Tech. 93, 229-245

Laca E.A., Ungar E.D., Demment M.W., 1994. Mechanisms of handling time and intake rate of a large mammalian grazer. Appl. Anim. Behav. Sci. 39, 3-19 